\title{
Національні тренувальні центри в системі підготовки професійних тенісистів Китаю
}

\author{
Ольга Борисова, Ші Шенін
}

Національний університет фрізичного виховання і спорту України, Київ, Україна

Анотація. Розробка стратегії і конкретних заходів з розвитку виду спорту з урахуванням соціально-економічних можливостей країни, організаційно-методичних основ розвитку тенісу у світі сприятиме не тільки підвищенню ефективності функціонування організаційноуправлінської системи тенісу в Китаї, а й сталому розвитку тенісу як соціально значущого виду спорту. Мета. Комплексний аналіз досвіду провідних світових центрів підготовки тенісистів-професіоналів, обґрунтування на цій основі системного підходу до формування національних тенісних центрів з урахуванням специфьіки організації спортивної підготовки в Китаї. Методи. Аналіз літературних джерел, нормативно-правових та регламентуючих документів, синтез, порівняння, конкретизація, систематизація, узагальнення, структурно-сункціональний аналіз, прогнозування і моделювання, опитування, бесіда, евристичне моделювання; історичний метод; методи математичної статистики. Результати. Центри підготовки тенісистів-професіоналів у системі організації та управління спортом в КНР дозволяють найбільш раціонально використовувати державні, громадські та приватні ресурси для ефективного розвитку виду спорту відповідно до темпів зростання соціальноекономічного рівня сучасного Китаю, відповідають соціальному запиту на спорт і потреби громадян країни.

Модель розвитку тенісу в Китаї передбачає три складові: методологічний базис - науковометодичні засади розвитку виду спорту, регулювання державного, громадського управління та приватних структур; систему забезпечення - формування нормативно-правових засад, що стимулює розвиток інфраструктури, розширення географії, створення системи маркетингу, інтеграція до міжнародної системи змагань з урахуванням принципової ролі Китаю в ній шляхом проведення престижних міжнародних турнірів; систему реалізації - впровадження сучасних технологій в організацію й проведення міжнародних та національних спортивних змагань, систему підготовки спортсменів різного рівня, удосконалення тренувального процесу та, що принципово важливо, розвиток дитячо-юнацького тенісу.

Ключові слова: теніс, тенісисти-професіонали, центри підготовки, організація і фуннкціонування.

\section{Olha Borysova, Shi Shengying}

\section{NATIONAL TRAINING CENTERS IN THE SYSTEM OF TRAINING PROFESSIONAL TENNIS PLAYERS IN CHINA}

Abstract. The development of a strategy and specific measures for the development of sports taking into account the social and economic potential of the country, organizational and methodological foundations of the development of tennis in the world not only will improve the organizational management system of tennis in China but also will promote sustainable development of tennis as a socially important sport. Objective. Integral analysis of the experience of the world's leading training centers for professional tennis players and substantiation on this basis of a systematic approach to the formation of national tennis centers taking into account the specifics of the organization of sports training in China. Methods. Analysis of the literature sources, regulatory and legal documents, synthesis, comparison, concretization, systematization, generalisation, structural and functional analysis, forecasting and modeling, survey, conversation, heuristic modeling, historical method, and methods of mathematical statistics. Results. Training centers for professional tennis players in the organizational management system of sports in the P. R. of China allow the most efficient use of government, public, and private resources for the effective development of sports in accordance with the social economic growth rate of modern China and meet the social demand for sports and the needs of the country's citizens.

Borysova 0., Shi Shengying. National training centers in the system of training professional tennis players in China. Theory and Methods of Physical education and sports. $2021 ; 3: 8-13$ DOI: $10.32652 /$ tmfvs.2021.3.8-13
Борисова О., Ші Шенін. Національні тренувальні центри в системі підготовки професійних тенісистів Китаю. Теорія і методика фрізичного виховання і спорту. 2021; 3: 8-13 DOI: $10.32652 /$ tmfvs.2021.3.8-13
16. World Cyber Games - [Електронний ресурс]. Режим доступу: https://en.wikipedia. org/ wiki/World_Cyber_Games)

Надійшла 26.08.2021

Вступ. Система сучасного спорту активно розвивається відповідно до соціальних запитів, юридичних й економічних законів, інших аспектів суспільного життя [1, 2, 4].

В останні десятиліття цей вплив був найсуттєвіший, що привело до кардинальної реорганізацій спорту взагалі, та його основних підсистем [5, 7 , 10]. Організаційно-управлінські основи сучасного спорту зазнали істотних змін [11-13, 15, 18], що відбулися під впливом як зовнішніх чинників, властивих світовому спорту (професіоналізація, комерціалізація, зближення професійного й олімпійського спорту, розширення міжнародного календаря змагань і ін.) $[2,11,19]$, так і внутрішніх, характерних для конкретної країни (місце спорту, законодавство, фрінансування, матеріальнотехнічна база тощо) $[4,6,8,14,16]$. Одним із характерних прикладів зазначених процесів $€$ фуннцціонування центрів підготовки професійних тенісистів, які організовані відповідно до вимог сьогодення та у своїй діяльності використовують передовий менеджмент, досвід провідних тренерських шкіл, формують найсучаснішу науково-методичну й матеріальнотехнічну бази, об'єднуючи традиції та особливості підготовки професійного й олімпійського напрямів спорту [3, 8, 9, 16-20].

Аналіз роботи провідних світових центрів є основою для формування організаційних передумов функціонування сучасної системи підготовки тенісистів високої кваліфікації, а їх досвід може бути використаний у реорганізації національних систем підготовки різних країн, зокрема в Китаї, де для цього склалися організаційні та соціальні умови, що і визначає безперечну актуальність дослідження. 
The model of tennis development in China includes three components: methodological basis: scientific and methodological principles of sports development, regulation of government and public administration and private structures; the system of support: the formation of the legal framework that stimulates the development of infrastructure, expanding geography, creating a marketing system, integration into the international competition system taking into account the fundamental role of China in it by holding prestigious international tournaments; and the system of implementation: the introduction of modern technologies in the organization and conduct of international and national sports competitions, the system of training athletes of different levels, improving the training process, and, importantly, the development of children's and youth tennis. Keywords: tennis, professional tennis players, training centers, organization and operation.

Розробка стратегії і конкретних заходів з розвитку виду спорту з урахуванням соціально-економічних можливостей країни, організаційно-методичних основ розвитку тенісу у світі сприятиме не тільки підвищенню ефективності функціонування організаційно-управлінської системи тенісу в Китаї, а й сталому його розвитку як соціально значущого виду спорту.

Дослідження є частиною науководослідної роботи, що проводилася відповідно до Зведеного плану НДР Національного університету фрізичного виховання і спорту України на 2016-2020 рр. за темою 2.20 «Удосконалення змагальної діяльності кваліфікованих спортсменів у спортивних іграх» (номер держреєстрації 0116U001627).

Мета дослідження - комплексний аналіз досвіду провідних світових центрів підготовки тенісистівпрофесіоналів, обґрунтування на цій основі системного підходу до формування національних тенісних центрів 3 урахуванням специсріки організації спортивної підготовки в Китаї.

Методи дослідження: аналіз літературних джерел; нормативно-правових та регламентуючих документів; теоретичні методи: аналіз, синтез, порівняння, конкретизація, систематизація, узагальнення, структурно-срункціональний аналіз; емпіричні методи дослідження: прогнозування і моделювання, опитування, бесіда; евристичне моделювання; історичний метод; методи математичної статистики (метод експертних оцінок).

Результати дослідження. Найбільш ефективною формою реалізації централізованої підготовки є створення і функціонування центрів спортивної підготовки, де сфокусовані людські ресурси в конкретному виді спорту або групи споріднених видів спорту, реалізовані всі необхідні компоненти життєдіяльності спортсменів: умови для тренування та відновлення, побут спортсменів, можливості отримання освіти. Сьогодні у світі в 47 країнах організовано підготовку спортсменівпрофесіоналів на базі академій тенісу. Проте, країнами-лідерами є лише вісім, які постійно виховують спортсменів міжнародного класу: Швеція, Бельгія, Велика Британія, Німеччина, Іспанія, США, Франція, Чехія, а провідними академіями є Sutton Tennis Academy (Лондон, Велика Британія), BTT Tennis Academy Valldoreix (Барселона, Іспанія), Bollettieri Tennis Academy Brenenton (Флорида, США), ISP Tennis Academy (Прага, Чехія), тенісна академія Ніколи Чіліча (Мюнхен, Німеччина), Good to Great Tennis Academy (Стокгольм, Швеція), де були виховані такі видатні тенісисти як Біллі Джин Кінг, Рафаель Надаль, Андре Агассі, Піт Сампрас, Борис Беккер, Штефі Граф, Новак Джокович, Роджер Федерер, Міхаель Штіх, Горан Іванішевіч, Станіслав Ваврінка та ін. $[11,13]$.

В основі роботи кожної з академій лежать загальні принципи організації підготовки тенісистів [2, 8, 16]. Разом з тим, практика показує відмінності не стільки у рівні підготовленості спортсменів, він досить високий у великої кількості спортсменів (про це свідчить висока конкуренція у світовому тенісі спортсменів першої сотні рейтингу ATP і WTA), скільки в стилі ведення гри, в особливостях реалізації технікотактичних дій тенісистів, умінні грати на певних покриттях тощо. Це підтверджує різноманітність методичних підходів, які використовують в системі підготовки тенісистів.

Систематизація особливостей роботи провідних світових тенісних центрів дозволить враховувати досвід світових тенісних держав країнами, які активно розвивають цей вид спорту. Серед них окреме місце посідає Китай, де нині відбувається найбільш активне становлення виду спорту, про що красномовно свідчать успіхи спортсменів на міжнародному рівні $[5,14]$. Враховування як загальних тенденцій, так і методичних особливостей організації системи спортивної підготовки створить основу для реалізації комплексного підходу до розвитку виду спорту в країні та сприятиме подоланню внутрішніх суперечностей.

Теніс у Китаї, як і будь-який інший вид спорту, в останні десятиліття опинився під інтенсивним впливом зовнішніх і внутрішніх фракторів. 3 одного боку, зміна політичного устрою країни, поліпшення економічного становища, стабільність соціальних і політичних аспектів життя, з іншого - відсутність конкурентного середовища, сформованої системи змагань, транссрерного ринку, що враховує інтереси національного тенісу. Зазначені тенденції не дозволили створити есективну систему підготовки тенісистів у країні, орієнтовану на участь як у національних, так і міжнародних змаганнях.

Разом $з$ тим, теніс як вид спорту дуже важливий для Китаю, що обумовлює необхідність визначення шляхів його розвитку, становлення організаційних форм підготовки спортсменів високого класу. Пріоритетність виду спорту в Китаї визначається не лише високою популярністю у світі і в країні, а й соціальною значущістю. Успішна участь представників країни у міжнародних срорумах, делегування провідних спортсменів на авторитетні міжнародні турніри та проведення їх в країні сприяє підвищенню престижності китайського спорту, фрормуванню позитивного іміджу і посиленню авторитету країни за кордоном.

Важливою проблемою для вирішення залишається пошук оптимального співвідношення національних інтересів китайської держави щодо міжнародного визнання та підготовкою спортсменів-професіоналів, централізацією підготовки провідних спортсменів й участю їх у національних і міжнародних професійних турнірах, за- 
безпечення необхідного рівня конкуренції на національному рівні шляхом організації престижних національних і міжнародних турнірів та фрормування мотивації участі у них провідних спортсменів країни.

Вивчення тенденцій і закономірностей розвитку світових тенісних центрів і застосування їх досвіду у процесі підвищення ефективності системи тенісу в Китаї має безперечну актуальність. Їх значущість визначена в плані розробки стратегії і конкретних заходів з розвитку виду спорту, приведення його у відповідність із соціальноекономічними можливостями країни і організаційно-методичними основами розвитку у світі, досягнення на цій основі стабільного функціонування тенісу як соціально значущого виду спорту в Китаї. Застосування досвіду світових тенісних держав безсумнівно підвищить ефективність цього процесу. Аналіз показав, що в Китаї сфрормовані історичні передумови для розвитку тенісу як соціально значущого компонента сучасного китайського суспільства.

Дискусія. На фрормування тенісу як виду спорту в Китаї впливають світові інтеграційні процеси, які мали значний вплив на динамічний розвиток виду спорту наприкінці XIX ст. Сфрормовані традиції підтримали суспільний запит на теніс як соціально значущий вид спорту в перехідний період нового Китаю.

Історичні передумови розвитку суспільства в Китаї зумовили бурхливий розвиток виду спорту в останні два десятиріччя. Соціально-економічний розвиток країни дозволив вийти на новий рівень функціонування виду спорту. Це чітко видно за статусом турніру професіоналів, участю в них провідних спортсменів світу і Китаю.

Розвиток виду спорту відповідно до законів Китаю дозволив подолати протиріччя, які існували протягом перехідного періоду становлення нового Китаю. Йдеться про сучасні вимоги профресійного тенісу і можливост його організації відповідно до запитів суспільства як фрактора активної спортивної, рекреаційної, розважальної та інфрормаційної функції.

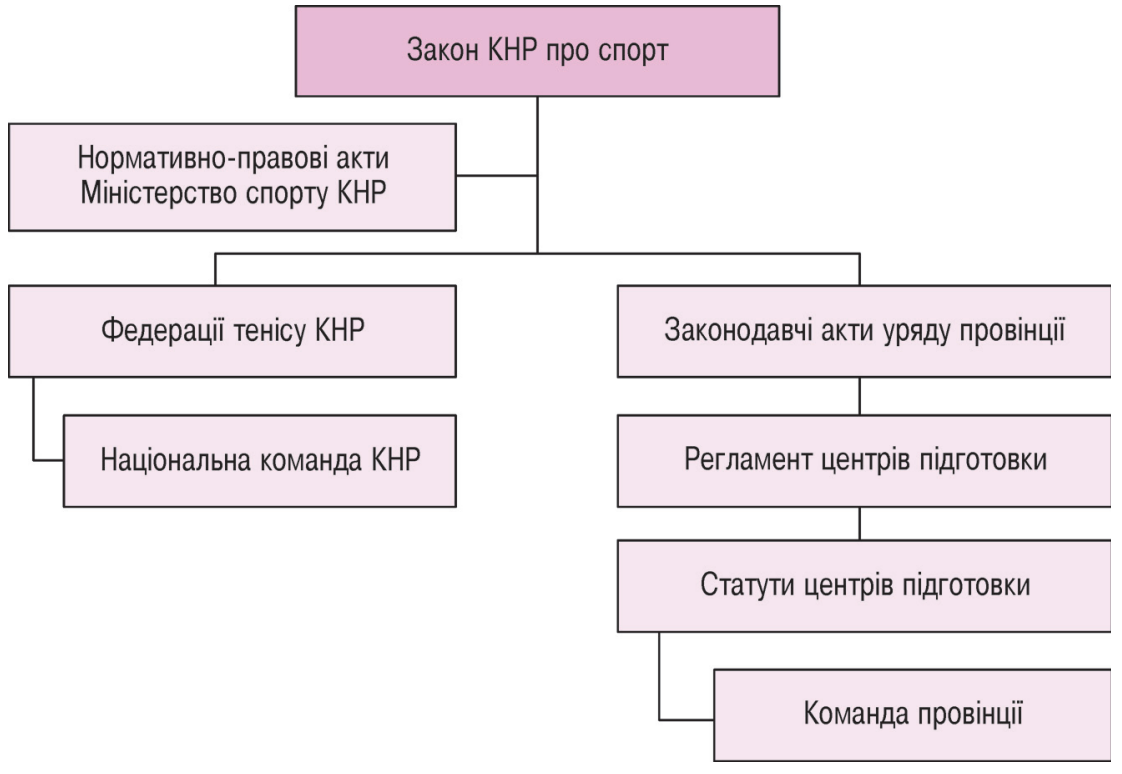

Рисунок 1 - Нормативно-правове регулювання діяльності центрів підготовки тенісистів провінції Шаньдун

Сучасні вимоги розвитку тенісу в Китаї вимагають повноцінного забезпечення тренувальної і змагальної діяльності. Організаційні форми, які сприяють розвитку виду спорту, спрямовані на формування спеціальних тенісних центрів, функціонування яких орієнтоване на міжнародний досвід, передовсім на науково-методичний потенціал, загальний фрінансово-економічний і законодавчий потенціал, місцеві особливості управління спортивними структурами. Формування на цій основі специфічних для Китаю центрів підготовки тенісистів вимагає проведення спеціального аналізу, розробки алгоритму вирішення питання і систематизації фракторів специфічних для Китаю і регіону.

За час становлення сучасного спорту в КНР сфрормувалася ефективна система управління, сформована на системних принципах організації спортивної підготовки. В її основі лежить інтеграція державних фоорм управління спортом, сучасний спортивний менеджмент, заснований на провідних аспектах світової практики і специфічних для Китаю форм організації спортивної підготовки і управління тренувальним процесом. У цілому система управління спортом $€$ унікальною структурою, що динамічно розвивається, соормування якої засноване на поєднанні державних, громадських і приватних фрорм управлін- ня і реалізації менеджменту в конкретних умовах Китаю, провінції, окремих регіонів.

В основі управління у сфері фрізичного виховання і спорту КНР лежить багаторівнева система, яка регулюється законодавчими актами і документами імплементації законів у практику організації підготовки спортсменів усіх рівнів. Як ієрархічну структуру розглядають комплекс документів, що регламентує діяльність системи спорту KHP (рис. 1).

На сучасному етапі, згідно з основними правилами, повноваження управління спортивними структурами передається громадським організаціям, причому йдеться про поєднання державного і приватного фінансування матеріально-технічного забезпечення спортивної підготовки, мотивації, забезпечення матеріального благополуччя спортсменів і їхніх родин в умовах суворо детермінованої централізованої підготовки. Визначено умови організації та управління тенісом на державному та громадському рівнях функціонування виду спорту. В Китаї ссрормовано унікальну систему управління спортом, у тому числі тенісом, яка регулюється законодавчими та нормативно-правовими актами, прийнятими Національними зборами Китаю, Міністерством спорту, Федерацією виду спорту. Принципово важливим є той фракт, що прийняті 
закони і законодавчі акти дозволяють, заохочують і створюють організаційні, соціально-економічні та інші умови для фрормування структур, які базуються на інтеграції форм державного, громадського та приватного управління в тій пропорції, яка є оптимальною для даного регіону, виду спорту, іншого об'єднання громадян КНP.

Такі структури є частиною системи спорту в КНР, регламентуються нормативно-правовими актами державних і громадських організацій:

- на національному рівні - держрадою КНР, Міністерством спорту, Асоціацією тенісу Китаю, національними командами Китаю;

- на регіональному рівні - органами державного управління спортом провінції (Центри підготовки спортсменів провінції), фредераціями та асоціаціями (об'єднаннями близьких за видами спорту фредерацій) видів спорту, командами 3 видів спорту провінції, міста (району).

Зміст законів і законодавчих актів дозволяє сфрормувати структури і вибрати найбільш раціональні форми підтримки в ссрері фрінансування та організації спортивної підготовки, які найбільш раціонально використовували б можливості держави, громадської та приватної ініціативи.

Це повною мірою реалізовано на рівні управління спортом провінцій, де враховані соціальний запит на конкретні види спорту і можливості його реалізації з урахуванням інтересів держави, провінції, спортсменів, працівників спортивного забезпечення. Одним 3 характерних прикладів реалізації такого підходу є формування регіональних структур управління видами спорту. На прикладі Федерації малих м'ячів показано можливість створення і раціональної діяльності федерацій, включаючи групи видів спорту, до структури якої входить і теніс. Створення таких структур пов'язане з реалізацією фракторів розвитку тенісу на сучасному етапі з урахуванням динаміки формування оптимальної структури управління видом спорту в Китаї, а саме: зниженні впливу держави на управління тенісними структурами, збереженні необхідних функцій управління державними структурами, що виражаються у фрінансуванні та матеріально-технічній підтримці дитячого спорту, стимулюванні приватних ініціатив; збільшення ролі громадського управління пов'язане з оптимізацією самої структури, передовсім, раціонального використання суспільних і соціально-економічних ресурсів провінції.

Системний підхід до перспективного розвитку тенісу ґрунтується на принципах цілісності, системності, ієрархічності, структуризації, множинності, ефективність реалізації яких базується на високому рівні соціальноекономічного розвитку країни. В результаті проведеного аналізу сучасних літературних джерел, нормативноправового регулювання, передового досвіду обґрунтовано шляхи формування науково-методичних основ розвитку і функціонування центрів підготовки тенісистів-профресіоналів, а евристичне моделювання стало базисом прогнозу успішного розвитку виду спорту в Китаї протягом семи років (на думку 82 \% респондентів).

Модель розвитку тенісу в Китаї передбачає три складові: методологічний базис - науково-методичні засади розвитку виду спорту, регулювання державного, громадського управління та приватних структур; систему забезпечення - формування нормативноправових засад, що стимулює розвиток інфраструктури, розширення географії, створення системи маркетингу, інтеграція до міжнародної системи змагань з урахуванням принципової ролі Китаю в ній шляхом проведення престижних міжнародних турнірів; систему реалізації - впровадження сучасних технологій в організації та проведенні міжнародних та національних спортивних змагань, системи підготовки спортсменів різного рівня, удосконаленні тренувального процесу та, що принципово важливо, розвитку дитячо-юнацького тенісу.

Аналіз динаміки розвитку тенісу в КНР дозволяє стверджувати, що протягом трьох, п'яти, семи років на розвиток спорту в країні будуть впливати різні чинники. Найбільш інтенсивний період розвитку прогнозується на п'ять-сім років, а саме (за результатами експертного опитування):
1-3 роки: зменшення ролі держави (80\%); розвиток інфрраструктури (30\%); розвиток дитячо-юнацького тенісу (7 \%); створення системи маркетингу (10\%); створення сприятливого інвестиційного клімату (40\%);

3-5 років: зменшення ролі держави $(20 \%)$; розвиток інфрраструктури (7\%); створення системи маркетингу (40\%); створення сприятливого інвестиційного клімату (8 \%); впровадження сучасних технологій організації та проведення спортивних змагань (10\%); впровадження сучасних технологій організації та проведення тренувального процесу (45 \%); інтеграція до міжнародної системи змагань $з$ урахуванням принципової ролі Китаю (18\%);

5-7 років: зменшення ролі держави (25\%); розширення геограсрії (60\%); створення системи маркетингу (25\%); створення сприятливого інвестиційного клімату (20\%).

Практичні аспекти реалізації прогнозу і моделі розвитку представлено на прикладі організації підготовки тенісистів-професіоналів провінції Шаньдун, де сьогодні відбуваються системні зміни. Конверсія державної форми управління в суспільну відбулася на прикладі трансформації Центру спортивного менеджменту видів спорту малих м'ячів провінції Шаньдун (Shandong Small Ball Sports Management Centre) у Федерацію видів спорту малих м'ячів провінції Шаньдун (Shandong Small Ball Sports Federation). Перехід припускав такий порядок дій:

1) кадрові зміни: створення секретаріату і відбір персоналу Федерації для забезпечення управління на основі відповідних нормативно-правових актів;

2) спортсмени: персональні справи 32 провідних спортсменів Центру спортивного менеджменту видів спорту малих м'ячів провінції Шаньдун передано в державну адміністрацію Центру підготовки спортсменів провінції Шаньдун (Shandong Sports Management Centre);

3) соціальний захист: забезпечення соціальних гарантій, в тому числі колишнім співробітникам Центру спортивного менеджменту видів 
спорту малих м'ячів провінції Шаньдун;

4) оптимізація структури управління: відповідність статуту Федерації малих м'ячів статуту громадських організації, визначених законодавством. Створення системи атестації кадрів;

5) ефективний менеджмент: залучення найбільш талановитих менеджерів в галузі спорту, економіки права, організації спортивної науки;

6) фрінансування: відповідність джерел фрінансування законодавству, в тому числі застосування державного фрінансування, акумуляція виділених коштів у Центрі підготовки спортсменів провінції Шаньдун;

7) мотивація: визначення завдань Центру відповідно до традицій регіону, організаційних і фінансових можливостей провінції;

8) інсрраструктура: залучення приватного капіталу та створення відповідних умов для будівництві інфрраструктури Федерації малих м'ячів;

9) система підготовки: Центр підготовки спортсменів провінції Шаньдун забезпечує підготовку та участь спортсменів провінції Шаньдун у Олімпійських, Азійських та національних іграх шляхом їх фрінансування, календар яких формується Федерацією спорту малих м'ячів провінції;

10) автономність: Федерація малих м'ячів користується повною автономією в контактах 3 національними і міжнародними спортивними організаціями

Центри підготовки тенісистів-професіоналів у системі організації та управління спортом в КНР дозволяють найбільш раціонально використовувати державні, громадські та приватні ресурси для ефективного розвитку виду спорту відповідно до темпів зростання соціально-економічного рівня сучасного Китаю, відповідають соціальному запиту на спорт і потреби громадян країни.

Аналіз структури моделі розвитку виду спорту дозволив виокремити три групи факторів, які впливають на розвиток виду спорту. Вони формують ієрархічну структуру взаємопов'язаних компонентів, кожен з яких забезпечує якісний розвиток виду спорту.
Перша група чинників представляє базис - систему державного, громадського управління, приватну ініціативу. Це чітко проявляється в процесі аналізу ролі держави і створення сприятливого інвестиційного клімату.

Друга група фракторів формує систему забезпечення виду спорту. До них відносять розвиток інфрраструктури, розширення географії, створення самостійної системи маркетингу, збільшення ролі і впливу міжнародної системи тенісу з урахуванням участі в ній Китаю.

Третя група чинників представляє систему реалізації виду спорту. Цей процес забезпечує впровадження сучасних технологій організації спортивних змагань, організації та проведення тренувального процесу, розвиток дитячо-юнацького тенісу.

В основу розвитку спортивних структур в КНР покладено фрілософрські та ментальні особливості, історичні передумови та соціальноекономічні можливості суспільства, які характеризують об'єкт не тільки описом його статичних характеристик, тобто змісту - форм управління, джерел фрінансування, менеджменту, а також і з систематизацією факторів його динамічного розвитку.

За цим принципом досягнута мета потребує оновлення та пошуку нових шляхів розвитку. Реалізація цього принципу заснована на загальних закономірностях фрормування системного підходу за умови наповнення конкретним змістом механізмів реалізації принципів системного підходу - цілісність, ієрархічність, структуризація, множинність, системність, а також розробки алгоритму конкретної послідовності дій із практичного впровадження в систему підготовки спортсменів.

Відмітною складовою реалізації системного підходу в системі спорту в Китаї $€$ супровід імплементації його принципів у практику обґрунтуванням конкретних дій, спрямованих на розвиток виду спорту, зокрема його структур у процесі короткострокової, середньострокової і довгострокової перспективи. При цьому акценти в розвитку зроблено на послідовну реалізацію поточних проєктів. Це де- монструє конкретні результати розвитку, дозволяє забезпечити можливості корекції шляхів розвитку.

Зміст законів і законодавчих актів дозволяє ссрормувати не тільки форми і зміст центрів підготовки тенісистів-профресіоналів, а й обґрунтувати процес розвитку з використанням найбільш раціональних форм законодавчої, юридичної, економічної і соціальної підтримки, найбільш раціонально використовувати можливості держави і громадської та приватної ініціативи.

Незмінними залишаються головні принципи, які декларовані в законі КНР про спорт, прийнятому законодавчими зборами Китайської Народної Республіки 29 серпня 1995 р. на 15-му засіданні Постійної комісії VIII Національного народного конгресу. Цей закон регламентує діяльність державних і громадських організацій з керівництва ссрерою спорту і тенісу, зокремa.

\section{Висновки:}

1. Аналіз даних спеціальної літератури і мережі Інтернет свідчить про відсутність системних знань про управління та організацію центрів підготовки тенісистів-професіоналів. Проте подальше удосконалення системи підготовки спортсменів високого класу, а також розвиток тенісу у світі і КНР передбачає розробку комплексного підходу і визначення ключових засад функціонування центрів 3 урахуванням нормативно-правових, соціально-економічних, науково-методичних і управлінських аспектів.

2. Історичні і сучасні аспекти розвитку тенісу в КНР формують передумови його успішного функціонування шляхом поєднання державних, суспільних і особистих інтересів. Сформовано соціальний запит на розвиток виду спорту в країні, розроблено нормативно-правові засади на рівні державного, суспільного і приватного регулювання діяльністю відповідно до світових стандартів, а також впроваджено науково-методичні засади.

3. Створення нормативно-правових основ не лише регулює розвиток спорту та діяльність спортивних організацій в країні, розподіл фуннкцій між державою, суспільними і приват- 
ними установами, а й створює умови для ефективного функціонування структур підготовки спортсменів різного рівня, зокрема центрів підготовки тенісистів-профессіоналів; сприяє масштабним інвестиціям, а також визначає самостійність у прийнятті організаційних і фінансових рішень.

Удосконалення організаційноуправлінської системи тенісу в Китаї відповідно до світових стандартів, належного рівня охоплення заняттями тенісом різних груп населення для сормування здорового способу життя громадян та забезпечення механізму відбору та підготовки обдарованих осіб для спорту вищих досягнень шляхом формування сучасної інфраструктури, а також підвищення авторитету країни на міжнародній арені забезпечує швидкий розвиток спорту в KHP.

Перспективи подальших досліджень передбачають вивчення та обґрунтування системи менеджменту тенісу на національному рівні, систематизацію засобів і методів управління тренувальним процесом 3 урахуванням цільових настанов та періодизації спортивної підготовки.

Конфлікт інтересів. Автори заявляють, що відсутній будь-який конфлікт інтересів.

\section{ЛITEPATУРA}

1. Бегнелл К. Роль спортивных центров Канады в реализации программы олимпийской подготовки. Взойти на пьедестал. Междунар. науч.-практ. конф. Тренировочные и соревновательные нагрузки в современном спорте. Киев; 2011.

2. Борисова ОВ. Современный профессиональный спорт и пути его развития в Украине: на материале тенниса: монография. Киев: Центр учебной лит.; 2011. 312 с.

3. Борисова 0, Петренко Г, Ши Шенін. Формування клубної системи у тенісі в Європі наприкінці XIX - на початку XX ст. Теорія і методика фріз. виховання і спорту. 2019;(1):89-92.

4. Бубка СН, Платонов ВН, редактори. Система олімпійської підготовки: основи менеджменту. Київ: Перша друкарня; 2018. 624 с.

5. Ву Хао. Система научного и медицинского обеспечения спортсменов олимпийской команды Китая. Наука в олимпийском спорте. 2009;(2):3-6.

6. Про фрізичну культуру і спорт: закон України № 1724-VI; 2009 Лист 17 [Інтернет] Доступно: https://zakon.rada.gov.ua/laws/ show/3808-12\#Text

7. Павленко Ю, Томашевский В. Система олимпийской подготовки спортсменов в Республике Корея. Наука в олимп. спорте. 2013;(1):89-91.
8. Павленко Ю, Козлова Н. Спортивные тренировочные центры в системе подготовки спортсменов. Наука в олимпийском спорте. 2013;(3):81-6.

9. Республиканский Олимпийский центр Озеро Круглое [Интернет]. Доступно: http:// www.sbok.ru

10. Avila F, Sanz D. Managing tennis business in times of crisis. ITF Coaching and Sport Science Review [Internet]. 2009;(48):18-9. Available from https://store.itftennis.com/home.asp

11. Barclays ATP World Tour Finals Partnership [Internet]. Available from: https://www.atptour.com/en/news/unicef-barclays-atp-world-tourfinals

12. Bohlke N. Elite sport organisation and management for world class performance [InDenmark. Available from: http://www.ucnorth.dk/ Home/EASM/EASM_Conference_2012

13. Bolletieri Sports Academy [Internet].

14. China State General Sports Administration [Internet]. Available from: www.chinasfa.net

15. Hong F, Wu P, Xiong H. Beijing ambitions: an analysis of the Chinese elite sports system and its Olympic strategy for the 2008 Olympic Games. The International Journal of the History of Sport. 2005;22(4):510-29

16. International Association High Performance Sports Training Centers [Internet]. Available from: http://www.forumelitesport.or

17. Korea National Traning [Internet]. Available from: http://www.sports.or.kr

18. Kozatek A, Uzhvenko K, Duchnova L, Radchenko L, Krol I, Ulan A, D'omina A, Borysova 0 , Denysova $L$, Shi Shengying. Sustainable development and the Olympic Movement. JPES. 2020;20(57):403-7.

19. Lin B. Starting and developing an academymarketing considerations [Internet]. ITF Coaching and Sport Science. 2009;(48):15-7. Available from: https://store.itftennis.com/home.asp

20. Olympic Training Centers [Internet]. Available from: www.teamusa.org/For-Athletes/Olym pic-Training-Centers-and-Sites.aspx

\section{LITERATURE}

1. Begnell K. The role of sports centers in Canada in the implementation of the Olympic training program. Climb the porium. Internat. scient.-pract. conf. Training and competitive loads in modern sports. Kiev; 2011.

2. Borysova OV. Modern professional sports and the ways of its development in Ukraine: on the basis of tennis material: monograph. Kiev: Tsentr uchebnoi literatury; 2011. 312 p. ternet]. In: 20-th EASM conference. Aalborg, Available from: http://www.sportline.bolletieri.com

3. Borysova 0, Petrenko G, She Shenin. Tennis club system formation in Europe at the end of the XIX - the beginning of the XX centuries. Theory and methods of physical education and sports 2019;(1):89-92.

4. Bubka SN, Platonov VN, editors. The system of Olympic preparation: the basics of management. Kyiv: Persha drukarnia; 2018. 624 p.

5. Wu Hao. The system of scientific and medical support of athletes of the Chinese Olympic team. Science in Olympic sport. 2009;(2):3-6.

6. Law of Ukraine "On Physical Culture and Sport" No. 1724-VI; 2009 Sheet 17 [Internet] Retrieved from: https://zakon.rada.gov.ua/laws/ show/3808-12\#Text

7. Pavlenko Yu, Tomashevskiy V. The system of Olympic training of athletes in the Republic of Korea. Science in Olympic Sport. 2013;(1):89-91.

8. Pavlenko Yu, Kozlova N. Sports training centers in the system of athletes' preparation. Science in Olympic sport. 2013;(3):81-6.

9. Republican Olympic Center Lake Krugloye [Internet]. Retrieved from: http://www.sbok.ru

10. Avila F, Sanz D. Managing tennis business in times of crisis. ITF Coaching and Sport Science Review [Internet]. 2009;(48):18-9. Available from https://store.itftennis.com/home.asp

11. Barclays ATP World Tour Finals Partnership [Internet]. Available from: https://www.atptour.com/en/news/unicef-barclays-atp-world-tourfinals

12. Bohlke N. Elite sport organisation and management for world class performance [Internet]. In: 20-th EASM conference. Aalborg, Denmark. Available from: http://www.ucnorth.dk Home/EASM/EASM_Conference_2012

13. Bolletieri Sports Academy [Internet] Available from: http://www.sportline.bolletieri.com

14. China State General Sports Administration [Internet]. Available from: www.chinasfa.net

15. Hong F, Wu P, Xiong H. Beijing ambitions: an analysis of the Chinese elite sports system and its Olympic strategy for the 2008 Olympic Games. The International Journal of the History of Sport. 2005;22(4):510-29.

16. International Association High Performance Sports Training Centers [Internet]. Available from: http://www.forumelitesport.or

17. Korea National Traning [Internet]. Available from: http://www.sports.or.kr

18. Kozatek A, Uzhvenko K, Duchnova $L$ Radchenko L, Krol I, Ulan A, D'omina A, Borysova 0 , Denysova L, Shi Shengying. Sustainable development and the Olympic Movement. JPES 2020;20(57):403-7.

19. Lin B. Starting and developing an academymarketing considerations [Internet]. ITF Coaching and Sport Science. 2009;(48):15-7. Available from: https://store.itftennis.com/home.asp

\section{ІНФОРМАЦІЯ ПРО АВТОРІВ}

Борисова Ольга Володимирівна https:orcid.org/0000-0002-2311-1921, borisova-nupesu@ukr. net

Національний університет фрізичного виховання і спорту України 03150, Київ, вул. Фізкультури, 1

\section{INFORMATION ABOUT THE AUTHORS}

Borysova Olha https:orcid.org/0000-0002-2311-1921, borisova-nupesu@ukr.net National University of Ukraine on Physical Education and Sport 03150, Kyiv, Fizkul'tury str., 1 